\title{
PENGARUH DEBT EQUITY RATIO TERHADAP REAL EARNINGS MANAGEMENT: ANALISIS FIRM LEVEL PERUSAHAAN MANUFAKTUR DI INDONESIA
}

\author{
THE EFFECT OF DEBT EQUITY RATIO ON REAL EARNINGS \\ MANAGEMENT: ANALYSIS FIRM LEVEL OF MANUFACTURING \\ COMPANIES IN INDONESIA \\ Ferica Christinawati Putri \\ Universitas Borneo Tarakan \\ fericacp@gmail.com
}

Abstrak : Penelitian ini bertujuan untuk mengetahui pengaruh DER (Debt Equity Ratio) terhadap keputusan melakukan manajamen laba riil pada perusahaan. Penelitian ini menggunakan Abnormal Cash Flow from Operation, Abnormal Production Cost dan Abnormal Discretionary Expenses dengan menggunakan model regresi Roychowdhury sebagai proksi dari manajemen laba riil. Dengan menggunakan sampel perusahaan sebanyak 92 perusahaan yang terdaftar di Bursa Efek Indonesia periode 2003-2014. Hasil penelitian dengan analisis level spesifik perusahaan menemukan bahwa DER berpengaruh signifikan positif terhadap manajemen laba riil

Kata kunci: Abnormal Cash Flow from Operation, Abnormal Production Cost dan Abnormal Discretionary Expenses, dan Manajemen Laba

Abstract : This study to determine the effect of DER (Debt Equity Ratio) on the decision to make real earnings management in the company. This study uses Abnormal Cash Flow from Operations, Abnormal Production Cost and Abnormal Discretionary Expenses by using the Roychowdhury regression model as a proxy for real earnings management. By using a sample of companies as many as 92 companies listed on the Indonesia Stock Exchange period 2003-2014. The results of research with a specific level of company analysis found that DER has a significant positive effect on real earnings managemen

Key words : Abnormal Cash Flow from Operation, Abnormal Production Cost dan Abnormal Discretionary Expenses, and earnings management

\section{LATAR BELAKANG}

Tanggung jawab untuk menyiapkan dan mempublikasikan informasi keuangan perusahaan ada pada manajer perusahaan. Idealnya, manajemen perusahaan akan menggunakan pengetahuan internal yang mereka miliki terkait dengan kondisi terkini dan lingkungan bisnis perusahaan untuk menyiapkan informasi, lalu informasi tersebut akan menggambarkan kondisi keuangan dan kinerja perusahaan. 
Untuk memenuhi kebutuhan tersebut informasi yang ada harus relevan dan reliable. Dalam kaidah pelaporan keuangan, laporan keuangan harus dilaporkan sebaik mungkin agar tidak menyesatkan stakeholder. Namun pada prakteknya, Standar Akuntansi Keuangan (SAK) memberikan fleksibilitas bagi manajemen untuk memilih kebijakan akuntansi yang lebih merepresentasikan keadaan perusahaan sesungguhnya. Fleksibilits itu yang terkadang dimanfaatkan oleh manajemen untuk melakukan manajemen laba. Oleh karena itu, manajemen mempunyai kecenderungan untuk melakukan tindakan yang dapat membuat laporan keuangan menjadi lebih baik. Rosenzweig (2002) menjelaskan bahwa manajemen laba adalah tindakan yang dilakukan manajer divisi yang bertujuan untuk meningkatkan atau menurunkan pendapataan yang dilaporkan saat ini tanpa kesesuaian peningkatan atau penurunan dalam keuntungan ekonomik jangka panjang divisi tersebut.

Beberapa penelitian manajemen laba terkini menyatakan pentingnya memahami bagaimana perusahaan melakukan manajemen laba melalui manipulasi aktivitas riil selain manajemen laba berbasis akrual Zamri (2013), Roychiwdhury ( 2006), dan Ghunny (2005). Pergeseran manajemen laba akrual ke manajemen laba riil ini menurut Rochowdhury (2006) karena pertama, manipulasi akrual akan menarik minat auditor atau regulatory scrunity dibandingkan dengan keputusan-keputusan real seperti penetapan harga dan produksi. Kedua, manipulasi akrual sangat berisiko karena jika realisasi akhir tahun defisit sedangkan laba tidak dimanipulasi dengan target laba yang diinginkan melebihi jumlah yang dimungkinkan untuk memanipulasi akrual setelah akhir periode fiskal maka laba yang dilaporkan akan turun dari target sehingga strategi berbasis akrual gagal dan manajer akan tidak mendapatkan kompensasi ataupun pemecatan.

Roychowdhury

menemukan bukti bahwa perusahaan menggunakan berbagai macam cara manajemen laba riil sebagai acuan pelaporan keuangan untuk menghindari pelaporan kerugian tahunan, hasil penelitiannya menemukan bahwa para manajer menyediakan tiga cara yaitu dengan melakukan diskon-diskon harga untuk menaikkan penjualan sementara, produksi secara besarbesaran untuk menurunkan kos barang terjual dan mengurangi pengeluaran diskresioner untuk memperbaiki margin yang dilaporkan.

Hasil penelitian Zamri (2013) menunjukkan bahwa Leverage berpengaruh negatif terhadap opportunity perusahaan melakukan praktek manajemen laba riil di Malaysia. Hal ini tidak menutup kemungkinan bahwa nilai Leverage berpengaruh terhadap manajemen laba riil di Indonesia. Sebab, Leuz (2003) menunjukan bahwa Indonesia memiliki lingkungan perlindungan investor yang lemah, sehingga praktik manajemen laba riil pada perusahaan di Indonesia cenderung lebih intensif dilakukan dibanding negara- 
negara lain. Sehingga penulis memfokuskan cakupan penelitian dengan memeriksa dampak Debt Equity Ratio (DER) pada manajemen laba riil terhadap perusahaan nonkeuangan di Indonesia periode 20032014 dengan menggunakan analisis spesifik level perusahaan untuk mengestimasi manajemen laba riil pertahun.

\section{PERUMUSAN MASALAH}

Berdasarkan latar belajang tersebut, maka yang menjadi pokok permasalahan dalam penelitian ini adalah sebagai berikut: Apakah perusahaan dengan tingkat $D E R$ yang semakin tinggi terlibat lebih besar dalam praktek manajemen laba riil dibandingkan perusahaan dengan tingkat $D E R$ yang lebih rendah?

\section{TINJAUAN PUSTAKA}

\section{Debt Equity Ratio (DER)}

Rasio total utang terhadap ekuitas pada penelitian ini menggunakan debt to equity ratio (DER). Total utang termasuk seluruh kewajiban lancar dan utang jangka panjang. Kreditor lebih menyukai ratio utang yang rendah karena semakin rendah ratio utang, makin besar perlindungan terhadap kerugian kreditor jika terjadi likuiditas. Perusahaan yang memiliki hutang besar, memiliki kecenderungan melanggar perjanjian hutang jika dibandingkan dengan perusahaan yang memiliki hutang lebih kecil (Mardiyah, 2005). Perusahaan yang melanggar hutang secara potensial menghadapi berbagai kemungkinan seperti, kemungkinan percepatan jatuh tempo, peningkatan tingkat bunga, dan negosiasi ulang masa hutang (Beneish dan Press, 1995 dalam Herawaty dan Baridwan, 2007).

\section{Manajemen Laba Riil}

\begin{tabular}{llr}
\multicolumn{1}{c}{ Manajemen } & laba riil dapat \\
didefinisikan & sebagai & tindakan- \\
tindakan & manajemen & yang
\end{tabular}
menyimpang dari praktek bisnis yang normal yang dilakukan dengan tujuan utama untuk mencapai target laba (Cohen dan Zarowin, 2010; Roychowdhury, 2006). Manajemen laba riil dapat dilakukan dengan 3 (tiga) cara yaitu:

1. Melakukan manipulasi penjualan merupakan usaha untuk meningkatkan penjualan secara temporer dalam periode tertentu dengan menawarkan diskon harga produk secara berlebihan atau memberikan persyaratan kredit yang lebih lunak. Strategi ini dapat meningkatkan volume penjualan dan laba periode saat ini, dengan mengasumsikan marginnya positif.

2. Melakukan penurunan bebanbeban diskresionari (dicretionary expenditures). Perusahaan dapat menurunkan discretionary expenditures seperti beban penelitian dan pengembangan, iklan, dan penjualan, adminstrasi, dan umum terutama dalam periode di mana pengeluaran tersebut tidak langsung menyebabkan pendapatan dan laba. Strategi ini dapat meningkatkan laba dan arus kas periode saat ini namun 
dengan resiko menurunkan arus kas periode mendatang.

3. Melakukan produksi yang berlebihan (overproduction). Untuk meningkatkan laba, manajer perusahaan dapat memproduksi lebih banyak daripada yang diperlukan dengan asumsi bahwa tingkat produksi yang lebih tinggi akan menyebabkan biaya tetap per unit produk lebih rendah. Strategi ini dapat menurunkan kos barang terjual (cost of goods sold) dan meningkatkan laba operasi.

\section{$\underline{\text { Risiko Keuangan }}$}

Risiko keuangan (financial risk) merupakan tambahan risiko yang dibebankan kepada pemegang saham biasa sebagai akibat dari keputusan untuk melakukan pendanaan utang. Secara konsep, pemegang saham akan menghadapi risiko dalam jumlah tertentu yang inheren dalam operasi perusahaan. Makin tinggi persentase utang dalam struktur modal, maka utang tersebut makin berisiko, sehingga makin tinggi tingkat bunga yang akan dikenakan oleh pihak pemberi pinjaman. DER yang tinggi menunjukan sumber pendanaan pada perusahaan berasal dari hutang, hal ini berkaitan dengan risiko keuangan yang akan dihadapi oleh perusahaan karena jika perusahaan tidak mampu menunjukan penampilan kemampuan likuiditas yang baik maka perusahaan akan mengalami kesulitan mendapatkan dana dari pihak eksternal. Maka perusahaan akan cenderung memanipulasi laba untuk mendapatkan kepercayaan dari kreditor. Hal ini menunjukan semakin tinggi leverage yang dimiliki maka perusahaan akan cenderung melakukan manipulasi laba atau dalam penelitian ini disebut sebagai manajemen laba riil.

\section{$\underline{\text { Hipotesis }}$}

Perusahaan dengan DER yang tinggi akan cenderung melakukan manipulasi dalam bentuk manajemen laba. Praktik manajemen laba ini dapat terjadi dikarenakan beberapa hal, pertama perusahaan dengan tingkat hutang yang tinggi memiliki risiko yang tinggi pula sehingga investor dan kreditor akan takut untuk berinvestasi atau meminjamkan dananya kepada perusahaan, kedua perusahaan akan terancam melanggar perjanjian hutang, ketiga dengan menggunakan banyak hutang dibandingkan modal sendiri maka beban tetap yang ditanggung perusahaan tinggi dan pada akhirnya akan menurunkan pendapatan perusahaan, dan keempat investor akan meminta tingkat keuntungan yang tinggi. Berdasarkan kondisi tersebut maka manajemen akan membuat kebijakan keuangan dengan melakukan manajemen laba untuk menaikan laba perusahaan.

H1: Perusahaan dengan tingkat $D E R$ tinggi cenderung terlibat dalam manajemen laba riil

\section{METODOLOGI PENELITIAN}

$\underline{\text { Desain Penelitian }}$

Penelitian ini bertujuan untuk melihat pengaruh DER terhadap manajemen laba riil. Variabel yang 
digunakan yaitu DER sebagai variabel independen, manajemen laba riil sebagai variabel dependen, dan variabel kontrol terdiri dari size dan growth. Khusus mengestimasi variabel manajemen laba riil menggunakan tiga proksi yaitu Abnormal CFO, Abnormal Disexp, dan Abnormal Production. Regresi yang digunakan menggunakan analisis spesifik level perusahaan. Untuk mendapatkan nilai kombinasi manajemen laba rill yang digunakan sebagai variabel dependen didapatkan dari penjumlahan residual leverage dengan menggunakan proksi DER, SIZE, dan GROWTH. Setelah itu regresi dengan menggunakan regression linear berganda hingga akhirnya dapat dibuat rangkuman yang berisi hasil dari setiap regresi tersebut.

Metode Analisis Data

Metode yang digunakan untuk menguji hipotesis adalah dengan menggunakan regresi linear berganda. Model statistik ini digunakan untuk mengukur DER terhadap manajeman laba rill. Berikut ini adalah persamaan regresi dalam penelitian ini :

$$
\begin{array}{ll}
\text { COM_REM } & =a+\beta_{1} \text { DER }+\beta_{2} \text { Size }+\beta_{3} \text { Growth }+\varepsilon_{1} \ldots \ldots \ldots \ldots \ldots \ldots \ldots . .(3.4) \\
\text { Abnomal CFO } & =a+\beta_{1} \text { DER }+\beta_{2} \text { Size }+\beta_{3} \text { Growth }+\varepsilon_{1} \ldots \ldots \ldots \ldots \ldots \ldots \ldots . .(3.5) \\
\text { Abnomal Disexp } & =a+\beta_{1} \text { DER }+\beta_{2} \text { Size }+\beta_{3} \text { Growth }+\varepsilon_{1} \ldots \ldots \ldots \ldots \ldots \ldots \ldots \ldots(3.6) \\
\text { Abnomal Prod } & =a+\beta_{1} \text { DER }+\beta_{2} \text { Size }+\beta_{3} \text { Growth }+\varepsilon_{1} \ldots \ldots \ldots \ldots \ldots \ldots \ldots . .(3.7)
\end{array}
$$

Keterangan:

REM :Real Earnings Management

DER : Debt Equity Ratio

Size : Ukuran Perusahaan

Growth: Pertumbuhan Penjualan
Model statistik ini digunakan untuk mengukur leverage terhadap manajeman laba rill. Pengujian hipotesis dilakukan dengan cara melihat efisiensi $\beta 1, \beta 2$, dan $\beta 3$ dari model regresi linear berganda yang bernilai positif dan signifikan pada level alpha $1 \%, 5 \%$, dan $10 \%$.

\section{$\underline{\text { Pengujian Asumsi Klasik }}$}

Sebelum melakukan pengujian regresi, pengujian asumsi klasik perlu dilakukan terlebih dahulu. Analisis linier berganda perlu menghindari penyimpangan asumsi klasik terlebih dahulu agar tidak menimbulkan masalah dalam penggunaan analisis tersebut. Pengujian asumsi klasik dalam penelitian ini meliputi uji normalitas, multikolinearitas, heteroskedatisitas dan autokorelasi.

\section{Uji Normalitas}

Uji normalitas merupakan salah satu bentuk pengujian yang bertujuan untuk mengetahui apakah residual (error) yang diperoleh dari regresi terdistribusi normal ataukah tidak. Cara untuk menguji normalitas adalah dengan uji Kolmogorov-Smirnov untuk menentukan normalitas distribusi residual. Jika sig atau p-value $>$ 0,05 , maka data berdistribusi normal.

2. Uji Multikoloniaritas

Tujuan digunakannya uji ini adalah untuk menguji apakah pada model regresi ditemukan adanya korealsi antar variabel independen. Jika terdapat atau terjadi korelasi maka terdapat problem multikolonieritas. Model regresi 
yang baik seharusnya tidak terjadi korelasi diantara variabel independen.

\section{Uji Heterokedastisitas}

Uji asumsi klasik dengan uji heteroskedastisitas bertujuan untuk menguji apakah model dalam regresi terjadi ketidaksamaan varians dari residual satu pengamatan ke pengamatan lain. Heteroskedastisitas merupakan keadaan yang menyatakan variabel gangguan mempunyai varians yang tidak konstan.

\section{Uji Autokorelasi}

Uji autokorelasi bertujuan untuk menguji apakah dalam suatu model regresi linear terdapat korelasi antara kesalahan pengganggu. Jika terjadi korelasi, maka terdapat masalah autokorelasi. Model regresi yang baik adalah tidak terdapat autokorelasi. Pendekatan yang sering digunakan untuk menguji ada atau tidaknya autokorelasi adalah uji Durbin-Watson.

\section{HASIL DAN PEMBAHASAN}

$\underline{\text { Hasil }}$

data $\begin{array}{rr}\text { Penelitian ini } & \text { menggunakan } \\ \text { perusahaan } & \text { kategori }\end{array}$ Manufacture, Agriculture, Forestry and Fishing, serta Mining yang terdapat pada Bursa Efek Indonesia dengan perioda tahun observasi yang dimulai dari tahun 2003 hingga tahun 2014. Untuk melengkapi komponen perhitungan setiap variabel yang diuji penulis menggunakan data laporan keuangan perusahaan mulai tahun 2001 untuk melakukan perhitungan variabel yang digunakan pada tahun 2003. Penetapan kriteria pengambilan sampel memiliki tujuan untuk memperoleh sampel penelitian yang valid dan dapat mewakili populasi sampel yang ada.

Pemilihan sampel yang dilakukan oleh penulis pada akhirnya terdiri dari 85 perusahaan manufaktur dan 8 perusahaan non manufaktur yang konsisten terdaftar di BEI sejak tahun 2001 - 2014.

\section{Hasil Uji Instrumen Penelitian}

Statistik Deskriptif Variabel $\underline{\text { Penelitian }}$

Penelitian ini terdiri dari tiga jenis variabel yang digunakan. Variabel tersebut adalah variabel dependen, variabel independen, dan variabel kontrol. Manajemen laba riil sebagai variabel dependen yang diproksikan melalui tiga pendekatan yang dikembangkan oleh Roychowdhury (2006) yaitu melalui manipulasi penjualan, pengurangan biaya diskresioner, dan produksi yang berlebihan. Pengukuran kombinasi manajemen laba riil juga mengikuti model regresi yang dikembangkan oleh Cohen et al. (2008). DER (debt equity to ratio) merupakan variabel independen. Sedangkan variabel kontrol terdiri dari size dan growth.

Tabel 4.2

Statistik Deskriptif Variabel

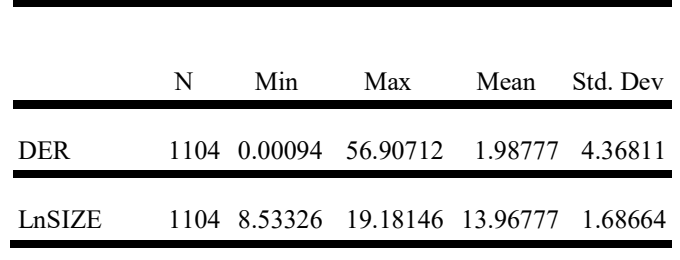

LnSIZE $\begin{array}{lllll}1104 & 8.53326 & 19.18146 & 13.96777 & 1.68664\end{array}$ 


\begin{tabular}{lrrrrr} 
GROWTH & 1104 & -0.9987 & 24.77632 & 0.23649 & 1.19444 \\
\hline ABN_CFO & 1104 & - & 81.49209 & -1.86241 & 2.95246 \\
& \multicolumn{5}{c}{7.72874} \\
\hline ABN_DIS & 1104 & - & 5.75846 & -2.06194 & 1.03002 \\
EXP & \multicolumn{5}{c}{6.70890} \\
\hline ABN_PRO & 1104 & - & 2.49722 & -1.59714 & 1.55329 \\
D & \multicolumn{5}{c}{9.43348} \\
\hline ABN_CO & 1104 & - & 5.85423 & -1.44478 & 1.33227 \\
MREM & \multicolumn{5}{c}{6.80340} \\
\hline Valid N & 1104 & & & \\
(listwise) & & & & & \\
\hline
\end{tabular}

Sumber: Data yang diolah

Variabel independen yang diproksilan melalui DER yang menunjukkan rasio modal terhadap kewajiban perusahaan memiliki nilai minimum 0.00094 yang berasal dari PT HM Sampoerna Tbk pada tahun 2013 dan nilai maksimum sebesar 56.90712 dimiliki oleh PT Multi Prima Sejahtera Tbk pada tahun 2011. Variabel dependen ABN_CFO yang menunjukan abnormal arus kas memiliki nilai minimum senilai 7.72874 yang berasal dari PT Davomas Abadi Tbk pada tahun 2013 dan nilai maksimum sebesar 81.49209 yang berasal dari PT Kedawung Setia Industrial Tbk pada tahun 2011. Variabel dependen ABN_DISEXP sebagai proksi dari aktivitas riil perusahaan dalam pengurangan biaya diskresioner memiliki nilai minimum sebesar 6.70890 di tahun 2005 pada PT Inter Delta Tbk dan memiliki nilai maksimum sebesar 5.75846 di tahun 2007 pada PT Ciputra Development Tbk. Variabel dependen ABN_PROD sebagai proksi dari manipulasi laba melalui aktivitas riil yaitu produksi yang yang berlebihan memiliki nilai minimum -9.43348 dan nilai maksimum sebesar 2.49722 pada PT Steady Safe Tbk di tahun 2008. Untuk kombinasi dari manajemen laba riil diproksikan sebagai ABN_COMREM memiliki nilai minimum sebesar -6.80340 di tahun 2003 terdapat pada PT Pudjiadi And Sons Tbk sedangkan nilai maksimum 5.85423 berasal dari PT Ciputra Development Tbk, 2007.

\section{Hasil Pengujian Hipotesis}

Sebelum melakukan pengujian hipotesis, terlebih dahulu dilakukan pengujian regresi pada persamaan (3.1), persamaan (3.2), dan persamaan (3.3) untuk mendapatkan nilai residual masing-masing yang akan digunakan sebagai proksi manajemen laba riil dan kemudian akan dijumlahkan menggunakan kombinasi manajemen laba riil seperti yang telah dilakukan oleh Cohen et al. (2008) untuk melihat total keseluruhan nilai residual dari masing-masing persamaan (3.1), persamaan (3.2), dan persamaan (3.3). Pengujian ini dilakukan dengan cara firm level analysis yang dilakukan per perusahaan sebanyak 11 tahun setiap masing-masing persamaan. Setelah mendapatkan nilai resiudal dari masing-masing persamaan maka tahap pertama telah selesai, lalu pengujian terhadap hipotesis daat dilakukan. Pada proses pengujian hipotesis untuk mengatasi distribusi variabel yang tidak normal saat uji normalitas maka dilakukan absolut dan Ln (Logaritma Natural) pada variabel dependen: ABN_COMREM, ABN_CFO, ABN_DISEXP, dan 
ABN PROD. Setelah melakukan regresi ulang dengan menggunakan residual yang telah diabsolutkan dan Ln dan mendapatkan hasil distribusi variabel yang normal maka tahap pengujian untuk persamaan (3.4), persamaan (3.5), persamaan (3.6), dan persamaan (3.7) dapat dilakukan.

Berdasarkan hasil regresi model 3.4 (COM_REM) yang secara total menunjukan bahwa DER berpengaruh signifikan terhadap kombinasi manajemen laba riil pada level alpha 1\%. Variabel kontrol yang diproksikan sebagai size juga berpengaruh negatif $-0,119$ dan signifikan pada level alpha $1 \%$. Variabel kontrol growth juga berpengaruh signifikan pada level alpha $1 \%$.

Berdasarkan hasil regresi model 3.5 (ABN_CFO) secara total hanya DER yang berpengaruh signifikan terhadap manipulasi penjualan (ABN_CFO) pada level alpha 1\%. Pada tahun 2006 size berpengaruh secara negatif terhadap ABN_CFO dengan beta $-0,214$ pada level alpha 5\%, tahun 2008 size berpengaruh negatif dengan beta 0,191 pada level alpha $5 \%$, dan tahun 2009 size juga berpengaruh negatif dengan beta $-0,305$ pada level alpha $1 \%$. Growth pada tahun 2008 berpengaruh negatif terhadap ABN_CFO dengan level alpha $1 \%$.

Berdasarkan hasil regresi model 3.6 (ABN_DISEXP) secara total DER signifikan pada level alpha $1 \%$. Hal ini didukung oleh hasil regresi pada tahun 2003, 2005, 2006, 2007, dan 2009 yang signifikan pada tingkat alpha $1 \%$.

Berdasarkan hasil regresi model 3.7 (ABN_PROD) secara total size berpengaruh signifikan pada level alpha 5\% dan growth berpengaruh negatif pada level alpha 5\%. Pada tahun 2004 DER berpengaruh positif dengan beta 0,333 pada level alpha $1 \%$.

\section{Uji Asumsi Klasik}

$\underline{\text { Uji Normalitas }}$

Untuk pengujian normalitas dibutuhkan transformasi nilai residual ke dalam bentuk absolut dan Logaritma natural (Ln) pada setiap model, yaitu model 3.4, model 3.5, model 3.6, dan model 3.7 untuk mendapatkan distribusi data yang normal.

\section{Uji Multikoloniaritas}

Tujuan digunakannya uji ini adalah untuk menguji apakah pada model regresi ditemukan adanya korealsi antar variabel independen. Jika terdapat atau terjadi korelasi maka terdapat problem multikolonieritas. Model regresi yang baik seharusnya tidak terjadi korelasi diantara variabel independen. Cara mendeteksi ada atau tidaknya multikolinearitas adalah dengan menggunakan nilai VIF (Variance Inflation Factor) pada masing - masing variabel bebas. Jika nilai tolerance $>0,10$ dan nilai VIF mendekati angka 1, maka dapat dikatakan bahwa tidak terjadi multikolinearitas.

Berdasarkan hasil yang terdapat pada tabel model regresi dapat dilihat bahwa tidak terjadi multikolinearitas antar variabel bebas, yang mana pada tabel tersebut menunjukkan nilai tolerance pada seluruh variabel pada masing-masing 
uji regresi lebih dari 0,10 dan nilai VIF mendekati angka 1.

\section{Uji Heterokedastisitas}

Model regresi yang baik adalah model regresi yang tidak terjadi heteroskedastisitas. Pengujian terhadap heteroskedastisitas dapat dilakukan dengan menggunakan uji glejser, yang mana pengujian tersebut mengusulkan untuk menilai absolute residual terhadap variabel independen. Uji ini dilakukan dengan cara meregresikan absolut residu pada variabel bebas. Hasil signifikansi dari model regresi absolut residu yang homoskedastisitas adalah yang bernilai $>0,05$. Apabila terdapat satu saja variabel yang memiliki nilai signifikansi $<0,05$ dapat dilakukan WLS (Weighted Least Squares Regression).

\section{Uji Autokorelasi}

Uji autokorelasi bertujuan untuk menguji apakah dalam suatu model regresi linear terdapat korelasi antara kesalahan pengganggu. Jika terjadi korelasi, maka terdapat masalah autokorelasi. Dalam penelitian ini tidak terdapat autokorelasi.

$\underline{\text { Pembahasan }}$

Pengaruh DER terhadap Real Earnings Management

Hipotesis akan dikatakan terdukung jika DER dalam penelitian model $\quad 3.4 \quad$ (COM REM) berpengaruh positif dan signifikan terhadap kombinasi manajemen laba riil. Hal ini menunjukan bahwa DER yang semakin tinggi akan membuka opportunities manajemen untuk melakukan manajemen laba melalui aktivitas riil. Peningkatan hutang akan mengakibatkan tingginya rasio DER. Hal ini berarti semakin besar pula beban bunga yang harus dibayar perusahaan yang pada akhirnya akan mempengaruhi besar kecilnya laba bersih yang akan diterima. Hal ini akan berdampak pada reaksi investor dan kreditor yang takut untuk berinvestasi dan memberi pinjaman karena melihat kemampuan likuiditas perusahaa dari perbandingan kewajiban dan ekuitas yang dimiliki perusahaan sehingga manajemen akan cenderung melakukan manajemen laba untuk menaikan laba.

Total pada kombinasi manajemen laba rill terlihat pada model 3.4 (ABN_COMREM), berdasarkan hasil uji siginifikan terlihat bahwa perusahaan telah melakukan manajemen laba riil sejak tahun 2003 yang secara signifikan pada level $1 \%$ melakukan manajemen laba riil pada saat risiko finansial perusahaan yang diproksikan oleh DER tinggi. Hal tersebut terlihat pada tahun 2003, 2005, 2006, dan 2007. Perusahaan juga melakukan praktik manajemen laba riil pada saat ukuran perusahaan (size) rendah dan tingkat growth yang tinggi memicu manajemen untuk melakukan manajemen laba pada aktivitas manipulasi penjualan, penurunan beban-beban deskresioner, dan produksi yang berlebihan.

Untuk melihat pengaruh variabel independen dan kontrol secara detail maka dapat digunakan model persamaan ABN_CFO (3.5), ABN_DISEXP (3.6), ABN PROD (3.7) yang telah diregresi per tahun. 
Pada tahun 2013, perusahaan dengan tingkat risiko keuangan yang tinggi melakukan manipulasi penjualan untuk meningkatkan laba dengan beta 0,212 dan signifikan pada level $1 \%$. Tindakan manajemen laba riil melalui manipulasi penjualan juga terjadi pada saat perusahaan memiliki tingkat size yang rendah, hal ini dapat terlihat pada tahun 2006 dengan koefisien beta $-0,214$ sig 5\%, 2008 dengan koefisien -0,191 pada level alpha 5\%, dan pada tahun 2009 dengan koefisien beta $-0,305$ yang signifikan pada level alpha 1\%. Selanjutnya, aktivitas manajemen laba riil melalui manipulasi penjualan pun dilakukan pada saat growth yang rendah pada tahun 2008 dengan koefisien beta 0,289 yang signifikan pada level alpha 1\%. Namun, pada tahun 2013 pada saat koefisien growth bernilai positif, perusahaan juga melakukan manipulasi penjualan hal ini didukung oleh signifikan pada level $1 \%$.

Manajemen laba riil melalui aktivitas penurunan beban deskresioner yang terdiri atas penjumlahan beban iklan, beban riset dan pengembangan, beban umum dan administrasi, dan beban penjualan pun dilakukan pada saat perusahaan sedang mengalami risiko yang tinggi. Hal ini dapat terlihat dari hasil regresi total pengaruh risiko keuangan yang diproksikan menggunakan DER terhadap aktivitas penurunan beban-beban deskrisioner yang ditunjukan dengan koefisien beta total DER sebesar 0,110 yang signifikan pada level alpha $1 \%$.

Manipulasi laba dengan aktivitas produksi besar-besaran terjadi pada saat perusahaan memiliki tingkat risiko finansial yang tinggi dengan koefisien beta 0,333 dan signifikan pada alpha level $1 \%$ di tahun 2004. Pada tahun 2004, 2006, dan 2009 perusahaan berturut-turut melakukan produksi berlebihan pada saat size perusahaan yang rendah dengan koefisien $-0,224,-0,212$, 0,217 pada tingkat signifikan pada alpha 5\%. Pada tahun 2013 terdapat perusahaan yang melakukan manipulasi laba melalui aktivitas produksi dengan growth yang tinggi yaitu dengan koefisien beta 0,238 yang signifikan pada level 5\%.

Debt to equity ratio (DER) merupakan rasio yang menunjukan perbandingan antara total hutang dengan modal sendiri. Rasio ini menunjukan hubungan antar jumlah kewajiban dengan jumlah modal sendiri yang diberikan oleh pemilik perusahaan (Warsono, 2003:239). Semakin besar debt to equity ratio (DER) menunjukan semakin besar kewajiban yang ditanggung perusahaan dan nilai debt to equity ratio (DER) yang semakin rendah akan menunjukan semakin tinggi kemampuan perusahaan dalam memenuhi kewajibannya. Rasio DER yang tinggi menandakan bahwa perusahaan sedang mengalami risiko keuangan yang tinggi. Risiko ini akan mendapatkan reaksi dari pihak manajemen dan eksternal yang terdiri dari investor dan kreditor. Menurut Damayanti, (2008) dalam Perdana, (2012) menyatakan bahwa perusahaan dengan rasio hutang yang tinggi cenderung menggunakan prosedur akuntansi yang bersifat menaikan laba untuk mengamankan tingkat likuiditas perusaan tersebut di mata kreditor. Dengan demikian, 
manipulasi untuk meningkatkan laba dapat dilakukan dengan aktivitasaktivitas riil seperti memberikan diskon dan kredit, menekan bebanbeban diskresioner, dan memproduksi dengan tingkat yang tinggi. Kegiatan dari aktivitas riil tersebut akan mempengaruhi arus kas yang pada akhirnya akan berdampak pada peningkatan laba.

Perusahaan dengan tingkat risiko finansial yang tinggi akan berdampak pada beberapa hal bagi pihak internal maupun eksternal. Hal-hal tersebut antara lain:

1. Perusahaan akan mengalami kesulitan mendapatkan dana tambahan bahkan terancam default (gagal bayar terhadap hutang yang dimiiliki) dan kehilangan kepercayaan dari pihak kreditor

2. Investor akan bereaksi pada tuntutan untuk menaikan tingkat keuntungan karena tingkat risiko finansial yang tinggi

3. Beban tetap yang akan ditanggung perusahaan tinggi dan mengakibatkan pendapatan perusahaan rendah. Contoh sumber dana yang memiliki beban tetap adalah seperti hutang dan obligasi.

Roychowdhury

menyatakan bahwa manajemen dapat melakukan manipulasi untuk meningkatkan laba perusahaan. Dengan melakukan peningkatan laba manajemen akan tetap mendapatkan bonus atau pencapaian perusahaan dalam menghasilkan laba. Selain itu manajemen juga akan mampu mepertahankan reputasi perusahaan dengan pihak eksternal seperti investor dan kreditor.
Dalam menyikapi adanya pelanggaran atas perjanjian hutang yang telah jatuh tempo, manajer akan berupaya menghindarinya dengan memilih kebijakan akuntansi yang menguntungkan dirinya, seperti menstransfer laba periode mendatang ke periode berjalan, karena hal tersebut dapat mengurangi risiko 'default'. Dalam teori akuntansi positif Watts dan Zimmerman (1986) menyatakan tiga hipotesis yaitu, bonus plan hypothesis, debt covenant hypothesis, dan political cost hypothesis. Debt covenant hypothesis menyatakan bahwa ketika perusahaan mulai mendekati terjadinya pelanggaran terhadap perjanjian hutang, maka manajer perusahaan akan berusaha untuk menghindari terjadinya perjanjian hutang tersebut dengan memilih metode-metode akuntansi yang dapat meningkatkan laba. Pelanggaran terhadap perjanjian hutang dapat mengakibatkan timbulnya suatu biaya serta dapat menghambat kerja manajemen, sehingga dengan meningkatkan laba manajemen berusaha untuk mencegah atau setidaknya menunda hal tersebut.

Sehingga berdasarkan hasil analisis diatas maka penelitian ini dapat mendukung hipotesis $\mathrm{H} 1$ bahwa perusahaan yang memiliki tingkat DER tinggi cenderung akan melakukan manajemen laba riil. Dengan kondisi-kondisi yang akan dihadapi oleh pihak internal dan eksternal perusahaan seperti yang telah disebutkan oleh penulis maka manajemen akan menggunakan aktivitas riil untuk menaikan laba yang akan pada akhirnya akan berdampak pada kepercayaan pihak investor dan kreditor dan dapat 
terhindar dari default. Selain isu risiko, penelitian ini juga mengangkat isu perilaku manajemen sebelum dimulainya konvergensi IFRS untuk melakukan manajemen laba riil. Berdasarkan hasil penelitian ini, perilaku manajemen memanipulasi laba dengan aktivitas riil ramai dilakukan sebelum tahun 2008. Indonesia mengadopsi IFRS sejak tahun 2008 dan mengalami persiapa hingga tahun 2010. Praktik manajemen laba riil berkurang setelah masa adopsi dan persiapan terhadap IFRS yang sedang diberlakukan di Indonesia. Dengan demikian IFRS memiliki dampak untuk mencegah perilaku manajemen laba riil di Indonesia.

\section{KESIMPULAN}

Penelitian ini bertujuan untuk menguji pengaruh risiko finansial (Leverage) yang diproksikan dengan debt to equity ratio (DER) terhadap aktivitas riil perusahaan dalam memanipulasi laba.

Dengan menggunakan metode Roychowdhury (2006) penulis menyimpulkan bahwa pihak manajemen melakukan manajemen laba riil pada saat risiko finansial yang dihadapi perusahaan tinggi. Manajemen laba riil ini dilakukan melalui aktivitas manipulasi penjualan dan penekanan bebanbeban deskrisioner seperti: beban iklan, beban penjualan, beban administrasi dan umum, serta beban riset dan pengembangan.

Pada penelitian ini juga memperhatikan dampak dari konvergensi IFRS yang telah dilakukan sejak tahun 2008 terhadap pola perilaku manajemen yang menyimpang dengan melakukan manipulasi laba riil. Hasil penelitian membuktikan bahwa perilaku manajemen laba melalui aktivitas riil marak dilakukan sebelum konvergensi IFRS diterapkan.

\section{SARAN}

Saran-saran yang dapat diberikan untuk penelitian selanjutnya adalah sebagai berikut :

1. Penelitian selanjutnya diharapkan dapat menambahkan variabel tingkat pembayaran pajak perusahaan dan debt conevenant untuk membuktikan lebih jelas lagi tentang motivasi perusahaan dalam menerapkan manajemen laba riil untuk mengurangi laba.

2. Penelitian selanjutnya diharapkan dapat berkontribusi penjelasan yang lebih spesifik tentang bagian IFRS yang menyebabkan tindakan manajemen laba riil semakin berkurang.

\section{DAFTAR PUSTAKA}

Apriyani, Dwi (2006), Analisis Praktek Manajemen Laba Pada Perusahaan Manufaktur Yang Melakukan IPO dan Listed di BEJ Perioda 19972004,Undip

Bringham, Eguene F., Joel F., Houston (2001), Fundamental of Finansial Management , 8th edition, Harcourt Inc

Ferdawati. (2009), Pengaruh Manajemen Laba Riil Terhadap Nilai Perusahaan, Jurnal Akuntansi dan Manajemen ISSN, 4, 59-74

Ratmono, Dwi (2010), Manajemen Laba Rill dan Berbeasis Akrual: 
Dapatkah Auditor yang berkualitas mendeteksinya?, Simposium Nasional Akuntansi XII Undip

Roychowdhury, Sugata (2006), Earning Management Through Manajemen laba riil Manipulation, Journal Accounting and Economic, 42, 335-370.

Sartono, Agus (1994), Manajemen Keuangan Teori dan Aplikasi, Edisi 2, BPFE

Sinaga, Uli (2014), Update Konvergensi IFRS di Indonesia, DSAK IAI

Strydom, Maria., Skully, Michael., Veeraraghavan, Madhu (2014), Is The Accrual Anomaly robust to Firm-level analysis?, International Review of Finansial Analysis ,34, 157-165

U.Ujah, Nacasias., Brusa, Jorge (2014), Earning Management, Finansial Leverage and Cash Flow Volatility:An Anaysis by Industri, Journal of Bussines and Economic, ISSN 2155-7950, 338-348 
e-ISSN 2685-2977 Jurnal Ekonomika Volume XI Nomor 2 Juni 2020 